\title{
DIE MOEDER-KIND-VERHOUDING BY KINDERS MET 'N GESPLETE LIP EN/OF VERHEMELTE EN MINIMALE-BREIN- DISFUNKSIE
}

RONÉL STEENEKAMP B.A. (LOG) (PRET,)

Alberton Kinderleidingkliniek, Privaatsak X2805, Alberton, 1450.

\section{OPSOMMING}

Die doel van hierdie studie is om die invloed van 'n fisies waarneembare afwyking en 'n fisies nie-waarneembare afwyking op die moeder-kind-verhouding na te gaan. Die moeder-kind-verhouding by twee verskillende afwykings $\mathrm{nl}$, gesplete lip en/of verhemelte en minimale-brein-disfunksie is bestudeer.

Die verhouding tussen die moeder en haar kind is 'n kritiese faktor in die algemene ontwikkeling van die kind. Die kwaliteit van die verhouding kan 'n invloed hê op latere verhoudinge wat die kind in sy lewe aangaan. Daar is gevind dat pre-, peri- en postnatalegebeure hierdie verhouding kan beînvloed.

'n Werkhipotese is gestel nl. dat die moeder-kind-verhouding betekenisvol swakker is by die ondersoekgroepe as dié van die kontrolegroep. Ten einde die hipotese te bewys is "The Mother-Child-Relationship Evaluation"-vraelys ingevul deur moeders met kinders met die genoemde afwykings. Daar is egter gevind dat daar nie 'n beduidende verskil is in die moeder-kind-verhouding van moeders met kinders wat 'n gesplete lip en/of verhemelte het nie. Moeders met kinders met minimale-brein-disfunksie, is egter geneig on dié kinders te verwerp.

\section{SUMMARY}

The aim of this study is to investigate the influence of a physically observable defect and a non-observable defect on the mother-child relationship. Mother-child relationships of two defects viz. cleft lip and/or palate and minimal brain dysfunction were studied.

The relationship between a mother and her child is a critical factor in the overall development of the child. The quality of the relationship can influence the child's subsequent relationships. It has been found that pre- peri- and postnatal events can influence this relationship.

A working hypothesis was postulated viz. that the mother-child relationship is significantly weaker in the experimental groups than in the control group. To prove this hypotheses, the "Mother-Child-Relationship Evaluation" questionnaire was completed by mothers of children with the mentioned defects. However, it was found that there is no significant difference in the mother-child relationship in mothers of children with a cleft lip and/or palate. However, mothers of children with minimal brain dysfunction are inclined to reject these children.

Die verhouding wat bestaan tussen die moeder en haar kind met 'n gesplete lip en/of verhemelte of haar kind met minimále-breindisfunksie is van teoretiese en praktiese belang. Die moeder-kindverhouding is ' $n$ kritiese komponent in die aanpassing van elke kind op 'n latere stadium van sy lewe. Die verhouding het egter ook 'n invloed op die kind se spraak en taalontwikkeling. Enige teoretiese begrip van die kind met 'n gesplete lip en/of verhemelte of minimale-breindisfunksie en sy ontwikkeling, moet 'n 'studie insluit van die moeder se reaksie op die inisiële kennisneming van haar kind se probleem, hoe hierdie reaksie verander het met verloop van tyd, hoe hierdie reaksie 
bygedra het tot die kind se spraakvaardigheid asook die algemene aanpassing van die kind.

Die toepassing van hierdie kennis kom tot uiting in die beplanning van 'n remediërende program vir die kind. Die spraakterapeut moet bepaal wat die houding van die moeder is t.o.v. haar kind met 'n gesplete lip en/of verhemelte of minimale-brein-disfunksie en of hierdie verhouding ' $n$ invloed het op prognose of die spraakprobleem teenwoordig. Hierdie verhouding moet dus in ag geneem word by die opstel van 'n terapieprogram.

Die doel van hierdie studie is dus om die invloed van 'n fisies waarneembare afwyking en 'n fisies nie-waarneembare afwyking op die moeder-kind-verhouding na te gaan. Die vraag is of die moeder-kindverhouding by die kind met 'n gesplete lip en/of verhemelte of minimale-brein-disfunksie verskil in vergelyking met die moeder-kindverhouding by normale kinders.

Die verhouding tussen die moeder en kind is essensieel vir die voortbestaan en ontwikkeling van die kind. Hierdie verbintenis tussen die moeder en haar kind is waarskynlik die sterkste verbintenis wat die mens aangaan. Die aanvanklike verhouding is ' $n$ kritiese faktor in die algemene ontwikkeling van die kind. Meer spesifiek het dit 'n invloed op die intellektuele en verbaal-linguistiese ontwikkeling. Die sterkte en kwaliteit van hierdie verhouding kan ook 'n invloed hê op die latere verhoudings wat die kind in sy lewe aangaan. Die houding van die moeder kan ook die kind se aanvaarding van homself. en dus sy selfbeeld beïnvloed.

Tydens die periode van swangerskap vind daar baie emosionele skommelinge plaas, positief en negatief. Die moeder moet leer om haar verantwoordelikhede te verplaas van haarself na haar kind. Sy moet tot aanvaarding kom van die swangerskap en besef dat sy moeder word. Sy moet identifiseer met die fetus as integrale deel van haarself, maar ook van die fetus as individu. Hierdie aanvaarding ontstaan tydens die beweging van die fetus in die uterus.

Die perinatale periode is ' $n$ periode van uiterste sielkundige kwesbaarheid a.g.v. die fisiese en psigiese veranderinge wat plaasvind by die moeder en haar kind. Die geboorte is die klimaks van die swangerskap. Die moeder sien uit daarna om haar kind te aanskou. Die geboorte is die finale resultate van haar konflikte a.g.v. angs en vrees vir swangerskap en geboorte.

Gebeure tydens die geboorteproses kan die moeder beïnvloed in die ontwikkeling van 'n verhouding met haar kind. Indien dit nie 'n normale geboorte was nie, kan die moeder skuldig voel omdat sy beheer verloor het tydens die geboorteproses. Postnatale depressie kan hieraan toegeskryf word. Die moeder benut dus nie die periode direk na geboorte om 'n verhouding met haar kind te ontwikkel nie weens die invloed van verdowingsmiddels op haar en haar kind en postnatale ongerief. Die tydperk direk na geboorte word deur verskeie outoriteite as 'n uiters kritiese periode beskou in die ontwikkeling van die 
moeder-kind-verhouding. Die periode is baie kort en 'n komplekse interaksie bind die moeder en haar kind saam. Tydens die periode verkry die moeder oogkontak met haar kind, sy streel en soen hom, borsvoeding vind plaas en sy praat met die baba ten einde sy aandag te behou.

Gedurende die eerste paar weke na geboorte word interaksie hoofsaaklik deur die huil van die baba bewerkstellig. Die huil bring die moeder in die posisie waar visuele, olfaktoriese en taktiele stimuli van waarde is. Glimlag word ook gebruik om die moeder naby die baba te hou. 'n Glimlag is belonend vir die moeder, sy bly dus naby die baba en voorsien in sy behoeftes. Glimlag het vertroeteling tot gevolg en versterk vertroeteling, daarom is dit een van die belangrikste -reaksies in die moeder-kind-verhouding.

Vokalisasie word ook as 'n veranderlike in hierdie komplekse moeder-kind-interaksie beskou. Tydens interaksie is die moeder altyd besig om met haar baba te praat of te vokaliseer. Dit maak dus deel uit van haar stimulasie. Haar houding sal die hoeveelheid spontane ,gesprekvoering" bepaal. Die baba se reaksie op haar vokalisasie sal ook bepaal hoeveel sy met die baba gaan praat. Die moeder praat nie net met haar baba nie, maar moedig hom aan om ook met haar te praat. Klaus \& Kennel ${ }^{3}$ voel dat kommunikasie beweging insluit. Die baba beweeg in ooreenstemming met die volwassene se spraak. Die moeder sal dus met die baba praat om reaksie uit te lok.

Sosiale interaksie ontwikkel geleidelik uit hierdie vroeë verhouding met die moeder, namate die huil van die baba afneem en die tyd wat hy wakker is toeneem. Daar is dus nou meer geleentheid tot speelinteraksie. Een van die sterkste faktore in vroeë sosiale interaksie is spontane spel. Die baba sal baie meer babbel tydens spel, wat by die moeder die gevoel laat dat dit wat sy doen wel iets beteken. Indien die moeder by die kind is in vreemde situasies, tussen vreemde mense, sal die kind weg beweeg van haar en die nuwe omgewing ondersoek. Dit is belangrik dat die kind die moeder verlaat en leer omtrent die groter wêreld. Hy moet dus onafhanklik raak om te funksioneer as volwassene in die samelewing. Die kind moet in interaksie verkeer met die lewelose omgewing en met ander lede van sy sosiale omgewing behalwe die moeder. Die moeder-kind-verhouding moet nie hierdie eksplorasie verhoed nie.

Symonds ${ }^{9}$ onderskei tussen vier houdings wat by die moeder aanwesig kan wees t.o.v. haar kind nl. verwerping, oortoegeeflikheiá, oorbeskerming en aanvaarding. Aanvaarding teenoor verwerping word beskou as die fundamentele elemente van die verhouding. Dit is die mate van anvaarding wat die ander aspekte van die moeder se gedrag bepaal. Aanvaarding of verwerping van die kind word deur verskillende outoriteite as 'n primêre faktor in die etiologie van spraakprobleme beskou.

Die geboorte van 'n kind is die hoogtepunt van die moeder se verwagtinge en omsluit haar toekomsdrome, daarom is die geboorte 
van 'n kind met 'n gesplete lip en/of verhemelte 'n skok vir elke moeder. Die kind verskil van die beeld wat die moeder opgebou het tydens swangerskap. Die voorkoms van die kind beïnvloed die proses van eksternalisasie van 'n interne beeld wat gedurende die nege maande gegroei het. In plaas daarvan om die kind waarvan sy gedroom het te baar, het sy die een gebaar wat sy gevrees het sy sal baar. Die gevolg kan verwerping of oorbeskerming wees. Die moeder word dus oorweldig deur 'n konflik van positiewe en negatiewe gevoelens wat bewus of onbewus kan wees.

Verskillende vrae sal by die moeder ontstaan t.o.v. die uiterlike voorkoms van die kind, reaksie van die vader, familie en vriende, die oorsaak en oorerflikheid van die afwyking en finansiële probleme. Die reaksie van die moeder op dié vrae word bepaal deur die wyse waarop dit beantwoord word. Hierdie antwoorde bepaal die langtermyn probleme waarvoor sy nou te staan kom.

Voor optimale ontwikkeling van 'n moeder-kind-verhouding kan begin, moet die moeder haar skuld-, angs- en onsekerheidsgevoelens verwerk. Die kritiese periode word dus nie benut nie a.g.v. angs omtrent die kind se toestand, gevoelens van mislukking en hulpeloosheid en fisiese skeiding van die moeder en haar kind.

Sommige moeders kan nie tot aanvaarding kom van die kind met sy afwyking nie. Hulle verkeer vir maande in 'n toestand van selfverwyt en bejammering. As reaksie op haar negatiewe gevoelens teenoor haar kind, ontstaan skuldgevoelens wat die verhouding met haar kind van die begin af beinvloed. Dit het oorbeskerming tot gevolg.

Die feit dat meeste babas met 'n gesplete lip- en/of verhemelte nie geborsvoed kan word nie, dra ook by tot die emosionele konflik van die moeder. Die baba moet versigtig gevoed word, in 'n spesiale posisie gehou word, meer toegelaat word om winde op te breek en meer gereeld gevoed word. Die moeder moet spesiale voedingsmetodes gebruik wat die abnormaliteit van die kind beklemtoon. Voeding is nie meer 'n tyd van plesier en vertroeteling nie.

Die herstel van die lip en prepalatale spleet sal plaasvind gedurende die eerste drie maande na geboorte en voor die kind drie jaar oud is, sal die palatale spleet herstel word. Voordat die kind skool toe gaan, sal hy reeds twee, drie of vier operasies ondergaan het om die spleet bevredigend te herstel. Elke operasie impliseer skeiding van die moeder, narkose, pyn van die orale omgewing en tydelike beperking van die bewegings van die hande en arms om manipulering van die operatiewe areas te voorkom.

Skeidingsangs ontstaan by die kind en die moeder tydens hierdie operatiewe tydperk. Die moeder toon ook vrees t.o.v. operatiewe prosedures en gevolge. Die moeder-kind-verhouding is die primêre area van versteuring. Hospitalisasie onderbreek roetine en die lewenssiklus van die kind.

Die spraak en psigolinguistiese vermoëns van die kind is ook dikwels afwykend wat die gevolg is van orale onvermoëns, maar ook weens 'n 
gebrek aan stimulasie en die feit dat die kritiese periode nie ten volle benut is nie. Die moeder is bewus daarvan dat spraakprobleme voorkom by die kind en daarom moedig sy nie die kind aan om te praat nie. Daar word laer vereistes t.o.v. sy spraak- en taalgebruik gestel. Sommige moeders kritiseer van die begin af die kind se spraakpogings, wat by die kind die gevoel laat dat sy spraak onverstaanbaar is. Hy kan ook voel dat hy nie sy moeder tevrede stel nie. Hierdie spraakprobleme beklemtoon ook die kind se andersheid by die moeder en later by die kind self.

Die kind met 'n gesplete lip en/of verhemelte vereis voortdurende gespesialiseerde aandag en ondersoeke. Dit vereis finansieël baie van die ouers ten koste van ander behoeftes.

Die moeder ondervind dus uiterste angs t.o.v. haar kind se probleme tydens die groeitydperk. Die emosionele omgewing is dus gestrem van geboorte af en bly dikwels abnormaal tydens die opgroei van die kind. Die moeder ervaar verskillende houdings van familie, vriende en vreemde persone weens die andersheid van haar kind, wat die normale ontwikkeling van 'n verhouding met haar kind strem.

Precht ${ }^{7}$ beweer dat abnormaliteite tydens swangerskap en geboorte 'n uiters belangrike faktor is in die etiologie van neurologiese abnormaliteite. Hy vind dat tot $68 \%$ van kinders waar probleme pre- of perinataal voorgekom het, neurologiese abnormaliteite vertoon. Volgens Precht het $70 \%$ van hierdie neurologies gestremde kinders spiertremors getoon van alle liggaamspiere, asook hiperaktiwiteit, gedragsprobleme en emosionele onstabiliteit. Hulle het ook op 'n later stadium leerprobleme getoon op skool.

Die geboorte van 'n premature baba kan beskou word as 'n psigososiale krisis wat ' $\mathrm{n}$ besliste emosionele invloed op die moeder het. Sy moet eerstens die moontlikheid aanvaar dat sy haar kind kan verloor deur die dood. Tweedens moet sy die gevoel dat sy nie 'n normale kind kan baar nie, aanvaar en verwerk. Derdens moet sy na die inisiële skeiding, tydens die kritiese periode, 'n verhouding met haar kind opbou en vierdens moet sy aanpas by die bepaalde ontwikkeling van 'n premature baba.

Meeste van die moeders ervaar dus gevoelens van angs en skuld. Die feit dat die moeder van haar kind geskei word, verhoog haar skuldgevoelens. Die skeiding laat haar voel dat sy nie in staat is om na haar eie kind om te sien nie.

Die minimale-brein-disfunksie-sindroom, wat waarskynlik méestal die gevolg is van pre- of postnatale komplikasies, het 'n besliste invloed op die gedragspatrone van die kind, maar nie in so 'n mate dat die moeder professionele hulp verkry nie. So 'n kind kan die moeder egter uitermatig irriteer, wat oorangstigheid, oorbeskerming of verwerping van die kind tot gevolg kan hệ.

Die minimale-brein-disfunksie-sindroom kan in twee vorme voorkom nl. die hipokinetiese kind, wat ook dikwels hipotonies is, apaties, stadig en min drink en swak reageer op stimuli. Aangesien hierdie 
kind minder huil as die normale kind, beskou die moeder hom as 'n "soet" kind. Daar ontstaan dikwels by die moeder 'n vrees dat sy die slap baba kan seermak. Aangesien die kind swak reageer op stimuli, sal die moeder hierdeur beïnvloed word. Die moeder sal minder stimuli aan die kind bied, omdat hy minder stimuli bied en swak reageer op haar stimuli. Die baba se slaperigheid, huiwerige bewegings en reaksies en uitdrukkinglose gesig, kan die ontwikkeling van 'n normale moeder-kind-verhouding beïnvloed.

Meestal is hierdie kinders egter hiperaktiewe kinders, hipertonus kom voor, die baba huil baie, 'n lae drempel kom voor t.o.v. die mororefleks, hy word moeilik wakker, maar raak ook weer moeilik aan die slaap. Die kind word moeilik getroos as hy begin huil. 'n Lae frekwensie tremor word getoon. Hy skrik maklik en kom angstig voor. Voedingsprobleme word getoon. a.g.v. 'n swak suigrefleks en braking. Baie angs is by die moeders teenwoordig. Hulle voel dat hulle die kind mishandel en ontwikkel skuldgevoelens. Die kinders is dus nie maklike deelnemers aan die moeder-kind-verhouding nie en die ontwikkeling van 'n gebalanseerde verhouding word beïnvloed.

Precht $^{7}$ het gevind dat die moeders nie bewus was daarvan dat hierdie simptome tekens is van minimale-brein-disfunksie nie. Hierdie gedrag het by hulle kommer gewek en hulle geïrriteer. Hulle het hierdie simptome as deel van die kind se temperament en persoonlikheid beskou. Die gedrag het die moeder se gedrag en vertroeteling van haar kind beïnvloed. Die moeders het nie ' $n$ harmonieuse, positiewe houding teenoor hulle kinders geopenbaar nie. Die moeders was bekommerd of hulle die kind korrek hanteer. Die kind se gedrag het nie die moeder tevrede gestel nie en die gevolg was dat die moeder onrustig gevoel het.

Fisiese uitputting kom by die moeders voor, aangesien die kind uiters baie energie vereis van die moeder weens sy swak eet- en slaappatroon en ontydige gehuil. Die moeder is dus ongeduldig en geïrriteerd wat haar verhouding met hierdie kind, sowel as ander kinders in die gesin en die vader beînvloed. Dit lei tot rusies en wrywing. Vyandigheid kan ontstaan teenoor die kind wat lei tot oortoegeeflikheid of verwerping. Infantiliteit van die kind veroorsaak dat hy afhanklik bly van die moeder en wat daartoe lei dat sy die kind kan oorbeskerm.

Die moeder se emosionele houding, vyandigheid, angstigheid en depressie word oorgedra an die kind as verwerping. Die kind se reaksies is dan 'n terugvoering van die moeder se houding. Verwerping word getoon in die kind se soeke na liefde en pogings om aandag te kry in so 'n mate dat hy nie belangstelling ontwikkel in die buitewêreld nie.

Hierdie kinders toon kenmerkende ontwikkelingsprobleme, wat taalontwikkeling insluit, waarskynlik a.g.v. 'n vertraging in die maturasie van die dele van die brein wat betrokke is by motoriese koördinasie en taal. Hierdie spraak en taalprobleme word getoon in vertraagde ontwikkeling, artikulasie afwykings, hakkel en stamel. Sy 
taalontwikkeling is egter nie net stadig nie, maar manifesteer deur sy lewe in sy lees en spelprobleme en swak woordeskat. Hierdie probleme kan egter ook toegeskryf word aan 'n gebrek aan stimulasie tydens die kritiese periode en die houding van die moeder teenoor haar kind.

Uit hierdie literatuurstudie kan daar dus tot die gevolgtrekking gekom word, dat moeder-kind-verhoudings waarskynlik versteur kan wees by moeders met kinders wat 'n gesplete lip en/of verhemelte of minimale-brein-disfunksie het. Tydens die ontwikkeling van hierdie versteurde moeder-kind-verhouding is die kind se linguistiese en taalontwikkeling ook beïnvloed. Spraak en taalafwykings by hierdie kinders kan dus ook aan hierdie versteurde moeder-kind-verhouding toegeskryf word, afgesien van organiese afwykings teenwoordig.

\section{EKSPERIMENTELE ONTWERP}

1. HIPOTESE-STELLING

'n Nulhipotese-stelling word t.o.v. elke groep gestel.

$\mathrm{H}_{0}$ Daar is geen beduidende verskil tussen die moeder-kindverhouding van die onderskeie ondersoekgroepe en die kontrole groep nie.

'n Werkhipotese word hierteenoor gestel.

$\mathrm{H}_{1}$ Die moeder-kind-verhouding is betekenisvol swakker by die onderskeie ondersoekgroepe as dié van die kontrolegroep.

$\mathrm{H}_{2}$ Die moeder-kind-verhouding van die ondersoekgroepe is betekenisvol beter as dié van die kontrolegroep.

2. DOELSTELLINGS

Die doel van hierdie ondersoek is tweeledig $\mathrm{nl}$.

- Die bepaling van die aard van die moeder-kind-verhouding by moeders met 'n kind met 'n gesplete lip en/of verhemelte of minimale-brein-disfunksie teenoor moeders met normale kinders.

- Die berekening van die verband tussen bepaalde gesinsveranderlikes en die moeder-kind-verhouding.

\section{PROEFPERSONE}

Kriteria van seleksie

(a) Die kontrolegroep

Die moeders in die kontrolegroep mag geen kind hê met enige fisiese abnormaliteite of spraak-probleme nie. Die swangerskap en geboorte van die betrokké kind moet relatief normaal verloop het, geen voedingsprobleme moet voorgekom het nie, 'n relatief normale ontwikkelingsverloop moet voorgekom het en geen gedragsafwykings mag getoon word nie, aangesien hierdie faktore is wat die normale ontwikkeling van die moeder-kind-verhouding kan beïnvloed. 
(b) Die gesplete lip en/of verhemeltegroep

Die moeders moet een of meer kinders hê met 'n gesplete lip en/of verhemelte met gevolglike sekondêre probleme soos voedingsprobleme, spraak-afwykings, emosionele probleme, sosiale probleme, ortodontiese probleme en afwykings van gehoor.

(c) Die minimale-brein-disfunksiegroep

Die moeders moet een of meer kinders hê met minimale-breindisfunksie d.w.s. die kind moet 'n pre- of perinatale geboortegeskiedenis toon. Daar moet faktore aanwesig wees soos voedingsprobleme, die kind moet 'n huilerige baba gewees het, wat min geglimlag en vokaliseer het, met 'n vertraagde ontwikkelingsgeskiedenis. Die kind moet hiper- of hipo-aktief wees, gedragsprobleme toon, kort aandagspan asook emosionele onstabiliteit. Sover moontlik is die kind deur 'n spesialis as 'n kind met minimale-brein-disfunksie gediagnoseer. Die kind moet egter ook 'n spraakafwyking toon soos artikulasie- of taalafwykings, hakkel, stamel of disleksie.

Omskrywing van die groepe

Twee ondersoekgroepe is gebruik nl.

- Twintig moeders, waarvan vyftien Afrikaanssprekend was en vyf Engelssprekend, met 'n kind met 'n gesplete lip en/of verhemelte. Twaalf van hierdie kinders was seuns en agt dogters.

- Vier en twintig moeders, waarvan vyftien Afrikaanssprekend was en nege Engelssprekend, met 'n kind met minimale-breindisfunksie plus 'n spraakafwyking. Twintig van hierdie kinders was seuns en vier dogters.

Een kontrolegroep is gebruik bestaande uit-

- Vier en dertig moeders, waarvan sewe en twintig Afrikaanssprekend en sewe Engelssprekend was, met normale kinders d.w.s. kinders sonder 'n fisiese- of spraakgebrek. Sestien van hierdie kinders was seuns en agtien dogters.

Verskeie gesinsveranderlikes is sover moontlik konstant gehou by al drie groepe. (Tabel 1.)

Die gemiddelde ouderdom van die moeders, van al drie groepe, was 35 jaar, die gemiddelde aantal kinders wat die moeders gehad het, was drie kinders. Die gemiddelde geboorte-orde van hierdie kinders was twee en die gemiddelde ouderdom van die kinders was sewe jaar.

Die sosio-ekonomiese klas van hierdie groepe is ook sover moontlik konstant gehou deur besonderhede te verkry van die beroep van die vader, sowel as dié van die moeder asook die woonbuurt waar hulle woonagtig is. Die moeders kom oorwegend uit 'n gemiddelde-sosio-ekonomiese klas. 
TABEL I: Gesinsveranderlikes betrokke by die onderskeie groepe.

\begin{tabular}{|c|c|c|c|c|c|}
\hline Veranderlike & Gemiddeld & $\begin{array}{l}\text { Standaard } \\
\text { afwyking }\end{array}$ & $\begin{array}{c}T \\
\text { waarde }\end{array}$ & $\begin{array}{c}\text { Grade van } \\
\text { vryheid }\end{array}$ & $\begin{array}{l}\text { Beduiden- } \\
\text { heidsvlak }\end{array}$ \\
\hline \multicolumn{6}{|l|}{$\begin{array}{l}\text { Gemiddelde ouderdom } \\
\text { van moeder: }\end{array}$} \\
\hline Kontrole & 33,70 & 5,885 & & & \\
\hline Gesplete lip & 34,30 & 5,292 & $-0,37$ & 52 & 0,712 \\
\hline MBD & 35,33 & 3,931 & $-1,18$ & 56 & 0,243 \\
\hline \multicolumn{6}{|l|}{ Gemiddelde aantal } \\
\hline kinders: & & & & & \\
\hline Kontrole & 2,50 & 0,896 & & & \\
\hline Gesplete lip & 2,70 & 1,129 & $-0,72$ & 52 & 0,476 \\
\hline MBD & 3,16 & 1,129 & $-2,50$ & 56 & $0,015^{*}$ \\
\hline \multicolumn{6}{|l|}{ Gemiddelde } \\
\hline $\begin{array}{l}\text { geboorte-orde: } \\
\text { Kontrole }\end{array}$ & & & & & \\
\hline $\begin{array}{l}\text { Kontrole } \\
\text { Gesplete lip }\end{array}$ & $\begin{array}{l}1,13 \\
2,00\end{array}$ & $\begin{array}{l}0,898 \\
1,170\end{array}$ & $-0,93$ & 52 & 0,355 \\
\hline MBD & 2,16 & 1,239 & $-1,54$ & 56 & 0,130 \\
\hline \multirow{2}{*}{\multicolumn{6}{|c|}{$\begin{array}{l}\text { Gemiddelde ouderdom } \\
\text { yan kind: }\end{array}$}} \\
\hline & & & & & \\
\hline Kontrole & 6,91 & 2,800 & & & \\
\hline Gesplete lip & 6,90 & 4,621 & 0,01 & 52 & 0,991 \\
\hline MBD & 7,37 & 3,005 & $-0,60$ & 56 & 0,550 \\
\hline
\end{tabular}

*Beduidend op die 5\% vlak

4. TOETSMATERIAAL

Omskrywing van die toetsmateriaal

Die toetsmateriaal bestaan uit 'n vraelys nl. "The Mother-ChildRelationship-Evaluation"-vraelys. Die vraelys is opgestel deur Robert M. Roth ${ }^{8}$ en gepubliseer deur die Western Psychological Services, California. Die vraelys verskaf 'n meetinstrument vir die bepaling van moeders se houdings teenoor hulle kinders. Dit evalueer die moeder-kind-verhouding objektief in terme van vier houdingskale te wete:

Aanvaarding (A)-12 items

Oorbeskerming (OB) -12 items

Oortoegeeflikheid (OT) -12 items

Verwerping $(\mathrm{V})-12$ items

Twee pole word weergegee in hierdie vraelys nl. aanv́aarding teenoor nie-aanvaarding. Oorbeskerming, verwerping en oortoegeeflikheid is vorme van nie-aanvaarding. Die houding van die moeder kan 'n positiewe en negatiewe karakter toon. Dit is moontlik dat 'n moeder vyandig voel teenoor haar kind en die kind aanvaar.

Hierdie vraelys is vertaal in Afrikaans, taalkundig nagesien en deur 'n sielkundige aan die Universiteit van Pretoria goedgekeur as 'n betroubare weergawe van die oorspronklike.

The South African Journal of Communication Disorders, Vol. 27, 1980 
Kriteria van keuse

Die "Mother-Child-Relationship-Evaluation"-vraelys (MCRE) is gekies aangesien dit die enigste vraelys beskikbaar is wat gebaseer is op Medinnus en Johnson ${ }^{4}$ se teoretiese model wat verwerping teenoor aanvaarding asook oortoegeeflikheid en oorbeskerming as 'n houding teenwoordig by die moeder insluit.

Verder voldoen die vraelys ook aan die statistiese kriteria van betroubaarheid en geldigheid.

5. PROSEDURE

Verkryging van proefpersone

Name en adresse van kinders met genoemde afwykings is verkry van die kliniekhoofde aan die spraak- en gehoorkliniek van die Universiteit van Pretoria, van die spraakkliniek by die $H$. F. Verwoerdhospitaal in Pretoria, 'n remediërende onderwyseres in Pretoria en 'n chirurg in Pretoria. Name van moeders met normale kinders is verkry van 'n privaat Crechè in Pretoria en 'n staatsdepartement in Pretoria.

\section{Toepassing}

Die vraelyste is onder verskillende omstandighede aan die moeders oorhandig en ingevul. Sommige moeders het die vraelys ontvang van die terapeut betrokke by hulle kinders se spraakterapie, die vraelyste is by die kliniek ingevul of tuis. Sommige van die vraelyste is aan die moeders persoonlik oorhandig en tuis ingevul, ander vraelyste is aan die moeders gepos nadat hulle telefonies gekontak is. Alle moeders kon egter nie gekontak word nie; vraelyste is dus slegs uitgepos.

Die voltooide vraelyste is weer aan die betrokke terapeute oorhandig of aan die ondersoekster self. Vraelyste wat uitgepos is, is teruggepos.

\section{Nasien en berekening van skale}

Elke stelling word bereken in terme van 'n vyfpuntskaal. Regs van elke stelling word die skale aangegee nl. SS (Stem sterk saam), S (stem saam), O (onseker), V (verskil) en SV (sterk verskil). Die nommerwaardes 5-4-3-2-1 bokant die response is die individuele roupunte vir elke respons. Regs van elke stelling is die letters A-OB-OT-V-VD. Hierdie letters identifiseer die houdingsskale. Ten einde die roupunt te bereken van die houdingskăle van bv. verwerping (V) word al die nommerwaardes van die respons geïdentifiseer deur die letter $\mathrm{V}$, op te tel. Dieselfde metode word gevolg vir oorbeskerming (OB), oortoegeeflikheid (OT), aanvaarding (A).

Hoe hoër die skaaltelling, hoe sterker is die houding. Hoe laer die skaaltelling, hoe swakker is die houding. 
Statistiese verwerking

Die data is verwerk met behulp van die Universiteit van Pretoria se IBM 370 rekenoutomaat. Die "Statistical Package for the Social Sciences" (SPSS) rekenaarprogram is vir die doel gebruik. Die volgende subprogramme is betrek:

- Berekening van die beduidendheid van verskille tussen die groepe (T-toets).

- Produk-moment-korrelasie.

Die statistiese formules wat betrekking het op bogenoemde berekenings word deur Nie et $\mathrm{al}^{6}$ volledig bespreek.

\section{RESULTATE}

Agt en sewentig vraelyste is terugontvang en verwerk. Hiervan was 34 van toepassing op die kontrolegroep, 24 op die minimale-breindisfunksiegroep en 20 op die gesplete verhemeltegroep. (Die bevindings word in Tabel 2 tot 6 weergegee.)

\section{DIE AARD VAN DIE MOEDER-KIND-VERHOUDING}

Dit blyk dat daar 'n statisties beduidende verwerpingsingesteldheid teenwoordig is by die moeders met kinders met minimale-breindisfunksie en 'n spraakafwyking. Alhoewel nie statisties beduidend nie, neig hierdie moeders ook om hulle kinders te oorbeskerm. Hierdie resultate kom ooreen met dié van ander studies. Aangesien hierdie kinders uiters baie energie vereis a.g.v. hulle swak eet- en slaappatroon, ontydige gehuil, hiper- of hipoaktiwiteit, emosionele onstabiliteit en swak aandagspan, kan daar by die moeder 'n vyandigheid ontstaan teenoor die kind wat daartoe lei dat die moeder die kind verwerp. Infantiliteit van die kind veroorsaak dat hy afhanklik bly van die moeder wat daartoe lei dat sy hom oorbeskerm. Precht ${ }^{7}$ bevestig hierdie resultate in sy studie "The mother-child interaction in babies with Minimal Brain Damage" (sien Tabel 2).

Daar kan tot die gevolgtrekking gekom word dat daar nie 'n beduidend nie (sien Tabel 3). Hierdie resultate kom ooreen met dié kinders en moeders met gesplete lip en/of verhemeltekinders nie. Daar is egter 'n neiging tot oorbeskerming, maar dit is nie statisties beduidend nie (sien Tabel 3). Hierdie resultate kom ooreen met dié van Goodstein. ${ }^{1,2}$ Goodstein vind ook geen beduidende verskil in die gesindheid van moeders met kinders met 'n gesplete lip en/of verhemelte nie en moeders met normale kinders nie. Die neiging tot oorbeskerming by die moeders kan verklaar word deur Palmer se semantiese teorie. Hy beweer dat 'n semantiese fout ontstaan a.g.v. die "gesond-siek" digotomie. Die moeder beskou dus haar kind met 'n gesplete lip en/of verhemelte as 'n ,,siek' kind en neig om hom te oorbeskerm. 
2. DIE VERBAND TUSSEN DIE BEPAALDE GESINSVERANDERLIKES EN DIE MOEDER-KIND-VERHOUDING

Die verband is ook bereken tussen die houding van die moeder en die bepaalde gesinsveranderlikes vir die drie groepe gesamentlik. Dit is gedoen volgens Pearson se produk-moment-korrelasietegniek (sien Tábel 4).

TABEL II: Beduidenheid van verskille in die moeder-kind-verhouding tussen die kontrolegroep en die Minimale-Brein-Disfunksiegroep

\begin{tabular}{|c|c|c|c|c|c|}
\hline Veranderlikes & Gemiddeld & $\begin{array}{l}\text { Standaard } \\
\text { afwyking }\end{array}$ & $\begin{array}{c}\mathrm{T} \\
\text { waarde }\end{array}$ & $\begin{array}{c}\text { Grade van } \\
\text { vryheid }\end{array}$ & $\begin{array}{l}\text { Beduiden- } \\
\text { heidsvlak }\end{array}$ \\
\hline $\begin{array}{l}\text { Oorbeskerming: } \\
\text { Kontrole } \\
\text { MBD }\end{array}$ & $\begin{array}{l}34,47 \\
37,75\end{array}$ & $\begin{array}{l}6,881 \\
6,589\end{array}$ & 1,82 & 56 & 0,074 \\
\hline $\begin{array}{l}\text { Verwerping: } \\
\text { Kontrole } \\
\text { MBD }\end{array}$ & $\begin{array}{l}32,05 \\
35,00\end{array}$ & $\begin{array}{l}4,445 \\
5,927\end{array}$ & 2,16 & 56 & $0,035^{*}$ \\
\hline $\begin{array}{l}\text { Oortoegeeflikheid: } \\
\text { Kontrole } \\
\text { MBD }\end{array}$ & $\begin{array}{l}31,88 \\
33,83\end{array}$ & $\begin{array}{l}5,068 \\
6,844\end{array}$ & 1,25 & 56 & 0,217 \\
\hline $\begin{array}{l}\text { Aanvaarding: } \\
\text { Kontrole } \\
\text { MBD }\end{array}$ & $\begin{array}{l}36,44 \\
36,37\end{array}$ & $\begin{array}{l}5,685 \\
6,398\end{array}$ & 0,04 & 56 & 0,967 \\
\hline
\end{tabular}

-Beduidend op die 5\% vlak.

TABEL III: Beduidenheid van verskille in die moeder-kind-verhouding tussen die kontrolegroep en die gesplete lip en/of verhemeltegroep

\begin{tabular}{|c|c|c|c|c|c|}
\hline Veranderlikes & Gemiddeld & $\begin{array}{l}\text { Standaard } \\
\text { afwyking }\end{array}$ & $\begin{array}{c}\mathrm{T} \\
\text { waarde }\end{array}$ & $\begin{array}{c}\text { Grade van } \\
\text { vryheid }\end{array}$ & $\begin{array}{l}\text { Beduiden- } \\
\text { heidsvlak }\end{array}$ \\
\hline $\begin{array}{l}\text { Oorbeskerming: } \\
\text { Kontrole } \\
\text { Gesplete lip }\end{array}$ & $\begin{array}{l}34,47 \\
38,05\end{array}$ & $\begin{array}{l}6,881 \\
7,097\end{array}$ & $-1,82$ & 52 & 0,074 \\
\hline $\begin{array}{l}\text { Verwerping: } \\
\text { Kontrole } \\
\text { Gesplete lip }\end{array}$ & $\begin{array}{l}32,05 \\
34,65\end{array}$ & $\begin{array}{l}4,445 \\
6,556\end{array}$ & $-1,73$ & 52 & 0,090 \\
\hline $\begin{array}{l}\text { Oortoegeeflikheid: } \\
\text { Kontrole } \\
\text { Gesplete lip }\end{array}$ & $\begin{array}{l}31,88 \\
33,15\end{array}$ & $\begin{array}{l}5,068 \\
5,153\end{array}$ & $-0,85$ & 52 & 0,382 \\
\hline $\begin{array}{l}\text { Aanvaarding: } \\
\text { Kontrole } \\
\text { Gesplete lip }\end{array}$ & $\begin{array}{l}36,44 \\
35,55\end{array}$ & $\begin{array}{r}5,685 \\
14,796\end{array}$ & 0,59 & 52 & 0,559 \\
\hline
\end{tabular}

Die Suid-Afrikaanse Tydskrif vir Kommunikasieafwykings, Vol. 27, 1980 
TABEL IV: Verband tussen bepaalde gesinsveranderlikes en die moeder-kindverhouding vir die drie groepe gesamentlik $(\mathrm{N}=78)$.

\begin{tabular}{|c|c|c|c|c|}
\hline Veranderlikes & $\begin{array}{l}\text { Oorbe- } \\
\text { skerming } \\
\underset{r}{\mathrm{r}}\end{array}$ & $\underset{r}{\text { Verwerping }}$ & $\begin{array}{l}\text { Oortoe- } \\
\text { geeflikheid } \\
\text { r }\end{array}$ & $\begin{array}{c}\text { Aanvaarding } \\
\mathrm{r}\end{array}$ \\
\hline Ouderdom van moeder & $\begin{aligned} & -0,0910 \\
p & =0,214\end{aligned}$ & $\begin{aligned} & 0,0738 \\
p= & 0,260\end{aligned}$ & $p=\begin{array}{l}0,0491 \\
0,335\end{array}$ & $\mathrm{p}=\begin{array}{l}0,0504 \\
0,331\end{array}$ \\
\hline Aantal kinders & $\begin{aligned} & -0,0061 \\
p & =0,479\end{aligned}$ & $\begin{aligned} & -0,0416 \\
p & =0,359\end{aligned}$ & $\begin{aligned} & -0,0295 \\
\mathrm{p} & =0,899\end{aligned}$ & $p=\begin{array}{l}0,0448 \\
p, 348\end{array}$ \\
\hline Geboorte-orde & $\begin{aligned} & -0,0429 \\
p & =0,354\end{aligned}$ & $\begin{aligned} & -0,0509 \\
p & =0,329\end{aligned}$ & $\begin{aligned} & =0,0441 \\
p & =0,351\end{aligned}$ & $\begin{array}{l}0,1143 \\
\mathrm{p}=0,159\end{array}$ \\
\hline Ouderdom van kind & $\mathrm{p}=0,0991$ & $\mathrm{p}=\begin{array}{l}0,2645 \\
0,110\end{array}$ & $p=0,0439$ & $\begin{aligned}-0,0673 \\
p=0,279\end{aligned}$ \\
\hline $\begin{array}{l}\text { Beroep: } \\
\text { vader }\end{array}$ & $\begin{array}{c}{ }^{* *} 0,2885 \\
p=0,005\end{array}$ & $\begin{array}{r}{ }^{*} 0,2141 \\
\mathrm{p}=0,030\end{array}$ & $\mathrm{p}=\begin{array}{l}0,1463 \\
0,101\end{array}$ & $\begin{array}{l}*-0,2103 \\
p=0,032\end{array}$ \\
\hline $\begin{array}{l}\text { Beroep: } \\
\text { moeder }\end{array}$ & 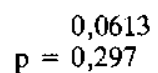 & $\begin{array}{l}* * 0,2862 \\
\mathrm{p}=0,006\end{array}$ & $p=\begin{array}{l}0,1463 \\
0,101\end{array}$ & $\begin{aligned} & -0,1155 \\
p & =0,157\end{aligned}$ \\
\hline
\end{tabular}

**Beduidend op die $1 \%$ vlak.

*Beduidend op die $5 \%$ vlak.

TABEL V: Verband tussen bepaalde gesinsveranderlikes en die moeder-kindverhouding by die Minimale-Brein-Disfunksiegoep $(\mathrm{N}=24)$

\begin{tabular}{|c|c|c|c|c|}
\hline Veranderlikes & $\begin{array}{l}\text { Oorbe- } \\
\text { skerming } \\
\mathbf{r}\end{array}$ & $\begin{array}{c}\text { Verwerping } \\
\mathbf{I}\end{array}$ & $\begin{array}{c}\text { Oortoe- } \\
\text { geeflikheid } \\
\ldots\end{array}$ & $\begin{array}{c}\text { Aanvaarding } \\
\mathrm{r}\end{array}$ \\
\hline Ouderdom van moeder & $\begin{aligned} & -0,1830 \\
p & =0,196\end{aligned}$ & $\begin{aligned} & -0,1792 \\
p & =0,201\end{aligned}$ & $\begin{aligned} & -0,1918 \\
p & =0,185\end{aligned}$ & $p=\begin{array}{l}0,2057 \\
0,167\end{array}$ \\
\hline Aantal kinders & $\begin{aligned}- & 0,1519 \\
p & =0,239\end{aligned}$ & $\begin{aligned} & -0,2598 \\
p & =0,110\end{aligned}$ & $\begin{aligned}- & 0,0356 \\
p & =0,434\end{aligned}$ & $p=\begin{array}{l}0,1233 \\
0,283\end{array}$ \\
\hline Geboorte-orde & $\begin{aligned} * & -0,3620 \\
p & =0,041\end{aligned}$ & $\begin{array}{c}*-0,3433 \\
p=0,050\end{array}$ & $\begin{aligned} & -0,2580 \\
p & =0,112\end{aligned}$ & $\mathrm{p} \stackrel{*}{=0,3975}=0,027$ \\
\hline Ouderdom van kind & $\begin{aligned} & 0,0686 \\
p= & 0,375\end{aligned}$ & $\begin{aligned} & 0,1904 \\
\mathrm{p} & =0,186\end{aligned}$ & $\begin{aligned} & 0,1110 \\
\mathrm{p}= & 0,303\end{aligned}$ & $\begin{aligned} & =0,0619 \\
p & =0,387\end{aligned}$ \\
\hline $\begin{array}{l}\text { Beroep: } \\
\text { vader }\end{array}$ & $\mathrm{p}=\begin{array}{l}0,0226 \\
0,458\end{array}$ & $\mathrm{p}_{,}^{\prime}=\begin{array}{l}0,3205 \\
0,063\end{array}$ & $p=\begin{array}{l}0,0254 \\
0,453\end{array}$ & $\begin{aligned} & -0,0524 \\
\mathrm{p} & =0,404\end{aligned}$ \\
\hline $\begin{array}{l}\text { Beroep: } \\
\text { moeder }\end{array}$ & $p=\begin{array}{l}0,2576 \\
0,112\end{array}$ & $\begin{aligned} & * 0,4326 \\
p^{*} & =0,017\end{aligned}$ & $\begin{aligned} * 0,3571 \\
\mathrm{p}=0,043\end{aligned}$ & $\begin{aligned} & -0,2568 \\
p & =0,113\end{aligned}$ \\
\hline
\end{tabular}

*Beduidend op die $5 \%$ vlak.

The South African Journal of Communication Disorders, Vol. 27, 1980 
TABEL VI: Die verband tussen bepaalde gesinsveranderlikes en die moederkind-verhouding by die gesplete lip en/of verhemelte groep $(\mathrm{N}=20)$

\begin{tabular}{|c|c|c|c|c|}
\hline Veranderlikes & $\begin{array}{l}\text { Oorbe- } \\
\text { skerming } \\
\underset{r}{\mathbf{r}}\end{array}$ & $\begin{array}{c}\text { Verwerping } \\
\mathbf{r}\end{array}$ & $\begin{array}{c}\text { Oortoe- } \\
\text { geeflikheid } \\
r\end{array}$ & $\begin{array}{c}\text { Aanvaarding } \\
\mathrm{r}\end{array}$ \\
\hline Ouderdom van moeder & $\mathrm{p}=\begin{array}{l}0,2966 \\
0,102\end{array}$ & $\mathrm{p}=\begin{array}{l}0,2110 \\
0,186\end{array}$ & $p=\begin{array}{l}0,0311 \\
0,448\end{array}$ & $\begin{aligned} & -0,2163 \\
p & =0,180\end{aligned}$ \\
\hline Aantal kinders & $p=\begin{array}{l}0,3108 \\
0,091\end{array}$ & $\mathrm{p}=\begin{array}{l}0,2340 \\
0,160\end{array}$ & $\begin{aligned} & -0,1457 \\
p & =0,270\end{aligned}$ & $\begin{aligned} & -0,0263 \\
p & =0,456\end{aligned}$ \\
\hline Geboorte-orde & $\mathrm{p}=\begin{array}{l}0,2346 \\
0,160\end{array}$ & $\mathrm{p}=0,0,365$ & $\begin{aligned} & -0,1048 \\
p & =0,330\end{aligned}$ & $\mathrm{p}=0,0,0563$ \\
\hline Ouderdom van kind & $\mathrm{p}=\begin{array}{l}0,3500 \\
0,065\end{array}$ & $p=0,042$ & $\mathrm{p}=0,0,440$ & $\begin{aligned} & -0,1494 \\
p & =0,265\end{aligned}$ \\
\hline $\begin{array}{l}\text { Beroep: } \\
\text { vader }\end{array}$ & $p=0,149$ & $p=\begin{array}{l}0,1667 \\
0,241\end{array}$ & $\begin{aligned} & -0,0174 \\
p & =0,471\end{aligned}$ & $\begin{aligned}- & 0,1532 \\
p & =0,260\end{aligned}$ \\
\hline $\begin{array}{l}\text { Beroep: } \\
\text { moeder }\end{array}$ & $\mathrm{p}=\begin{array}{l}0,1244 \\
0,301\end{array}$ & $\mathrm{p}=\begin{array}{l}0,1490 \\
0,265\end{array}$ & $\mathrm{p}=\begin{array}{l}0,1210 \\
0,306\end{array}$ & $\begin{aligned} & =0,1546 \\
p & =0,258\end{aligned}$ \\
\hline
\end{tabular}

Uit bogenoemde resultate kan afgelei word dat die veranderlikes, ouderdom van die moeder, aantal kinders, geboorte-orde en ouderdom van die kind geen invloed het op die houding van die moeder nie. Dit is egter in teenstelling met ander literatuur wat hierdie veranderlikes as belangrik beskou in die ontwikkeling van die moeder-kind-verhouding.

'n Positiewe verband bestaan egter tussen die beroep van die vader en oorbeskerming en verwerping (nie-aanvaardingsdimensies) by die moeder. Daar bestaan 'n negatiewe verband tussen die beroep van die vader en aanvaarding deur die moeder van haar kind. Hier kan dus afgelei word dat daar 'n groter ingesteldheid tot nieaanvaarding bestaan by moeders wat getroud is met mans in die sogenoemde laervlakberoepe.

'n Positiewe verband is ook gevind t.o.v. die beroep van die moeder en volgens hierdie bevindings blyk dit of moeders wat huisvrouens is, in 'n groter mate geneig is om hulle kinders te verwerp as werkende moeders.

Daar is 'n negatiewe verband tussen die geboorte-orde van die kind en oorbeskerming sowel as verwerping by kinders met minimalebrein-disfunksie (sien Tabel 5). Dit wil sê hoe laer die kind met minimale-brein-disfunksie in die geboorte-orde voorkom, hoe minder word hy oorbeskerm of verwerp deur die moeder. Hierdie neiging word bevestig deur 'n positiewe verband tussen die geboorte-orde van die kind en aanvaarding van die kind. Dit toon aan dat hoe laer die kind in die geboorte-orde voorkom, hoe meer 
word hy deur die moeder aanvaar. Eersgeborenes met minimalebrein-disfunksie sal dus meer oorbeskerm en verwerp word en minder aanvaar word as latere kinders.

Precht $^{7}$ beweer dat moeders met kinders wat minimale-breindisfunksie toon, die simptome van hulle kinders as deel van die kind se temperament en persoonlikheid aanvaar. Die kind word dus aanvaar, maar sy gedrag stel die moeder nie tevrede nie. Die moeder raak fisies uitgeput en geïrriteerd a.g.v. hierdie gedrag van die kind, wat daartoe lei dat sy die kind verwerp. Die infantiliteit van die kind gee aanleiding tot die moeder se oorbeskerming.

Medinnus en Johnson ${ }^{4}$ beweer dat moeders 'n baie sterker band met hulle eerste kinders opbou en dus baie meer betrokke is by die gebeure rondom die kind as latere kinders. Fisiese- of gedragsafwykings by eersgeborenes sal dus 'n baie groter invloed hê op die moeder se houding teenoor die kind.

'n Positiewe verband is ook gevind t.o.v. die beroep van die moeder en 'n nie-aanvaardingsingesteldheid. Dit blyk dat moeders wat huisvrouens is, in 'n groter mate geneig is om hulle kinders te verwerp, wat moontlik toegeskryf kan word aan die feit dat sy vir baie langer periodes blootgestel is aan dié kind met minimale-brein-disfunksie se gedrag. Sy is ook geneig om oortoegeeflik te wees teenoor die kind. Hierdie neiging kan toegeskryf word aan die feit dat daar aan die moeders gesê word dat die kind nie beheer oor sy gedrag het nie en dat sy dit nie kan verander nie. Sy gee dus makliker toe aan sy versoeke en ontoelaatbare gedrag.

Die ouderdom van die kind toon wel 'n beduidende verband met verwerping by kinders met 'n gesplete lip en/of verhemelte (sien Tabel 6). Hoe ouer die kind met 'n gesplete lip en/of verhemelte is, hoe groter is die verwerping. Hierdie resultate dui daarop dat die moeder, namate die kind ouer word, hom meer verwerp. Dit word bevestig deur Goodstein. ${ }^{1}$ Goodstein verklaar dit soos volg: . . . the effects on parental adjustment of having a child with this type of physical handicap in the home are not immediately evidenced but rather develop with time. Baie van die probleme by die kinders, soos spraakprobleme, ortodontiese probleme, chirurgies- of ander sekondêre probleme is nie aan die moeder bekend by geboorte nie, maar word belangriker namate die kind ouer word. Gepaardgaande emosionele en sosiale afwykings wat manifesteer in swak skoolprestasie en leerprobleme kan die moeder se verwerpingsingesteldheid versterk.

\section{GEVOLGTREKKINGS}

Daar kan nie tot die gevolgtrekking gekom word dat daar 'n beduidende verskil in die moeder-kind-verhouding van moeders met minimale-brein-disfunksie of gesplete lip en/of verhemelte kindes teenoor moeders met normale kinders is nie, aangesien bogenoemde resultate nie beduidend genoeg is nie. Dit kan die gevolg wees van die 
feit dat die groepe nie groot genoeg was nie en 'n normale verspreiding nie voorgekom het nie.

Die moontlikheid bestaan ook dat die "Mother-Child-RelationshipEvaluation"-vraelys nie sensitief genoeg is om verskille aan te toon in die houding van moeders met kinders met spesifieke abnormaliteite teenoor moeders met normale kinders nie. Goodstein ${ }^{1}$ en Moll \& Darley ${ }^{5}$ het ook gevind dat 'n enkele vraelys of toets nie voldoende is om ingesteldhede by ouers met kinders met spesifieke abnormaliteite teenoor ouers met normale kinders waar te neem nie.

Daar kan egter wel afgelei word dat moeders met kinders wat minimale-brein-disfunksie toon, geneig is om hierdie kinders te verwerp. Die verwerpingsingesteldheid van die moeders kan 'n bydraende faktor wees in die spraakafwykings wat by die kinders voorkom. As gevolg van die moeder se verwerping, is die kind voortdurend gefrustreerd, maar hy mag nie uiting gee aan die gevolge daarvan nie. Die kind moet hierdie aggressiewe gevoelens onderdruk en leer dus dat spraak 'n suksesvolle wapen is.

Die feit dat daar geen statisties beduidende verskil gevind is in die houding van die moeders met gesplete lip en/of verhemelte kinders nie, kan waarskynlik toegeskryf word aan die feit dat dié moeders reeds die afgelope aantal jare hulp ontvang vanuit 'n multidissiplinêre raamwerk.

Die nulhipotese word dus aanvaar $\mathrm{nl}$. dat daar geen beduidende verskil tussen die moeder-kind-verhouding van die onderskeie ondersoekgroepe en die kontrolegroep is nie.

Die werkhipotese $\left(\mathrm{H}_{1}\right.$ en $\left.\mathbf{H}_{2}\right)$ word dus verwerp $\mathrm{nl}$. dat die moeder-kind-verhouding betekenisvol swakker of beter is by die onderskeie ondersoekgroepe as dié van die kontrole groep.

Daar is ook gevind dat sommige gesinsveranderlikes wel 'n invloed kan hê op die moeder-kind-verhouding veral by moeders met kinders wat 'n gesplete lip en/of verhemelte het of minimale-brein-disfunksie.

\section{AANBEVELINGS}

Dit word aanbeveel dat, indien daar in verdere navorsing in die verband belangstel word, 'n battery toetse uitgevoer word eerder as 'n enkele toets, aangesien 'n enkele toets slegs een fasset toets en daar wel verskille op ander vlakke kan voorkom.

In verdere navorsing behoort daar veral klem gelê te word op die moeder-kind-verhouding by kinders met minimale-brein-disfunksie, aangesien hierdie studie wel 'n verwerpingsneiging uitgewys het by moeders met kinders wat minimale-brein-disfunksie toon.

\section{SLOT}

In die algemeen kan tot die gevolgtrekking gekom word dat die evaluering van die moeder-kind-verhouding met behulp van die "Mother-Child-Relationship-Evaluation"-vraelys van min waarde was 
in ' $n$ poging om die moeders van kinders met minimale-breindisfunksie of ' $n$ gesplete lip en/of verhemelte en hulle verhouding met dié kind beter te verstaan. Dit het egter wel aan die lig gebring dat moeders met kinders wat minimale-brein-disfunksie het, nie hulle kinders bevredigend aanvaar nie. Hierdie resultate beklemtoon weereens die belang van 'n multidimensionele benadering in behandeling van hierdie kinders.

\section{VERWYSINGS}

1. Goodstein, L. D. (1960a): Personality Test Differences in Parents of Children with Cleft Palates. J. Speech. Hear. Res. 3. p. 39-43.

2. Goodstein, L. D. (1960b): MMPI Differences between parents of children with cleft palates and parents of physically normal children. J. Speech. Hear. Res. 3. p. 31-37.

3. Klaus, M. H. \& Kennel, J. H. (1976): Maternal Infant Bonding C. V. Hosby St. Louis.

4. Meddinus, G. R. \& Johnson, R. C. (1969): Child and Adolescent Psychology: Behaviour and Development. Wiley \& Sons. NY.

5. Moll, K. L. \& Darley, F. L. (1960): Attitudes of mothers of articulatory impaired and speech retarded children. J. Speech. Hear. Dis. 25. pp. 377-384.

6. Nie, N. H. (1975): Statistical Package for the Social Sciences. McGraw Hill.

7. Precht, M. F. R. (1963): The Mother child interaction in Babies with minimal brain damage (a follow-up study). In Determinants of Infant Behaviour Vol. 2. Foss (Ed). Butler and Tanner Ltd. G. B.

8. Roth, M. R. (1961): The Mother Child Relationship Evaluation Western Psychological Services. California.

9. Symonds, P. (1949): Dynamics of Parent Child Relationships. Bureau of Publications N. Y. 


\section{Philips Hearing Aid Services}

A Division of S.A. Philips (Pty) Ltd.
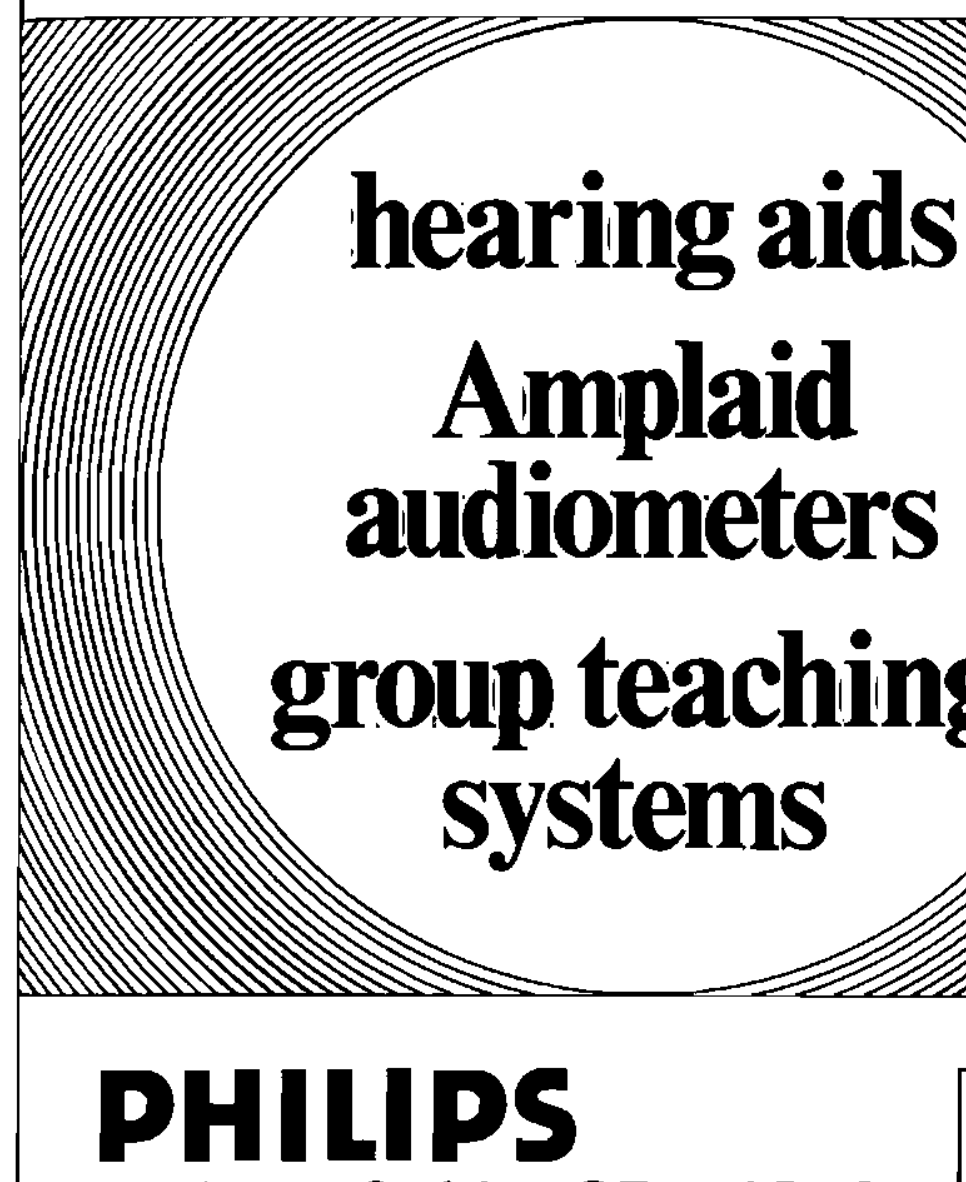

HEARING AID SERVICES

Head Office 1005 Cavendish Chambers, 183 Jeppe Street, P.O. Box 3069, JOHANNESBURG.

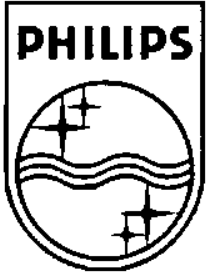




\section{Introducing ...}

TYMPAN-D-SCDPE

the impedance meter that uses an otoscope as the probe ...
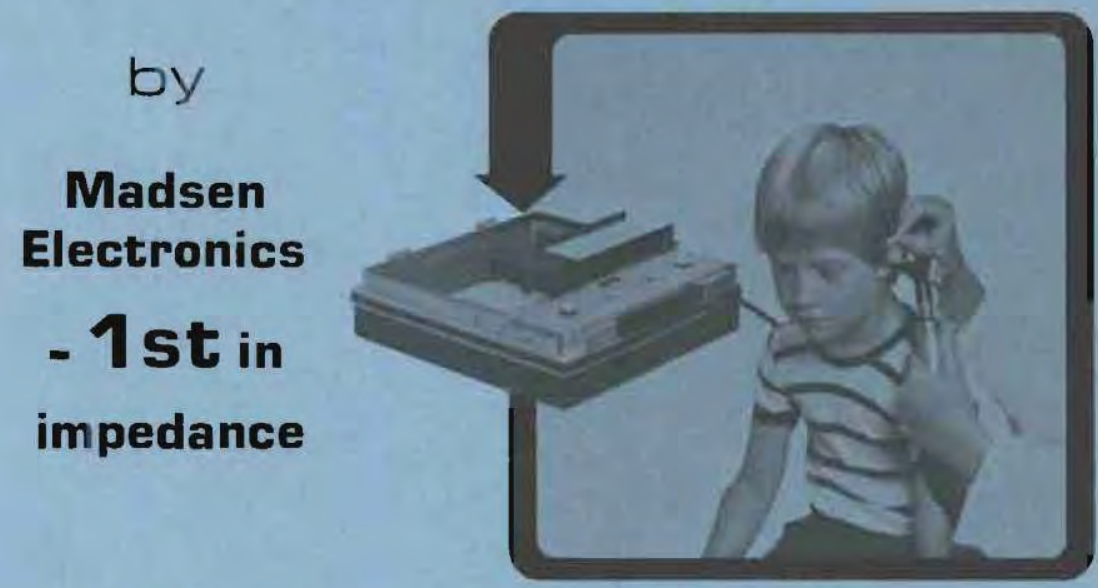

- Automatic - Performs all tests automatically

- Fast

- Complete lest takes only 10 seconds each ear

- Portable - Weighs only 15 lbs. $77 \mathrm{Kg}$ )

- Printout - IBM size card for easy filing

- Diagnostic - Results correlale with Madsen dinical instruments

- Screening - Pass/fail paramelers adjustable

- Otoscopy - Pressure finely controlled

- Tympanometry - From +200 to $-300 \mathrm{~mm} \mathrm{H}_{2} \mathrm{O}$

- Reflex - Ipsilateral in real time.

contact Ken Southcott or Richard Anderson at:

AMTRONIX (PTY) LTD

P.O. Box 630

Bedfordview

2008

Phone 615-7647/8/9 